University of Nebraska - Lincoln

DigitalCommons@University of Nebraska - Lincoln

Faculty Publications from the Harold W. Manter Laboratory of Parasitology

$10-2002$

\title{
Redescriptions of Haemonchus mitchelli and Haemonchus okapiae (Nematoda: Trichostrongyloidea) and Description of a Unique Synlophe for the Haemonchinae
}

\author{
J. Ralph Lichtenfels \\ Animal Parasitic Disease Lab, ARS, United States Department of Agriculture, 2jrcgl@gmail.com \\ Patricia A. Pilitt \\ United States Department of Agriculture \\ Lynda M. Gibbons \\ University of London \\ Eric P. Hoberg \\ United States Department of Agriculture, eric.hoberg@ars.usda.gov
}

Follow this and additional works at: https://digitalcommons.unl.edu/parasitologyfacpubs

Part of the Parasitology Commons

Lichtenfels, J. Ralph; Pilitt, Patricia A.; Gibbons, Lynda M.; and Hoberg, Eric P., "Redescriptions of Haemonchus mitchelli and Haemonchus okapiae (Nematoda: Trichostrongyloidea) and Description of a Unique Synlophe for the Haemonchinae" (2002). Faculty Publications from the Harold W. Manter Laboratory of Parasitology. 327.

https://digitalcommons.unl.edu/parasitologyfacpubs/327

This Article is brought to you for free and open access by the Parasitology, Harold W. Manter Laboratory of at DigitalCommons@University of Nebraska - Lincoln. It has been accepted for inclusion in Faculty Publications from the Harold W. Manter Laboratory of Parasitology by an authorized administrator of DigitalCommons@University of Nebraska - Lincoln. 


\title{
REDESCRIPTIONS OF HAEMONCHUS MITCHELLI AND HAEMONCHUS OKAPIAE (NEMATODA: TRICHOSTRONGYLOIDEA) AND DESCRIPTION OF A UNIQUE SYNLOPHE FOR THE HAEMONCHINAE
}

\author{
J. Ralph Lichtenfels, Patricia A. Pilitt, Lynda M. Gibbons*, and Eric P. Hoberg \\ Parasite Biology, Epidemiology, and Systematics Laboratory, Agricultural Research Service, U.S. Department of Agriculture, \\ The Henry A. Wallace Beltsville Agricultural Research Center, Beltsville, Maryland 20705-2350. e-mail: rlichten@anri.barc.usda.gov
}

\begin{abstract}
In the course of a revision of Haemonchus Cobb, 1898 (Nematoda), commonly referred to as large stomach worms, significant new morphological information was discovered that allows the recognition of 2 species believed for more than $50 \mathrm{yr}$ to be synonymous. Both species, Haemonchus mitchelli Le Roux, 1929, from the eland Taurotragus oryx and other African ruminants and $H$. okapiae van den Berghe, 1937, from the okapi Okapia johnstoni, have a synlophe of 42 ridges, but the synlophe of $H$. mitchelli is longer than that of $H$. okapiae. The distal tip of the left spicule of $H$. mitchelli bears a barb that is about twice as long as the short barb and half as long as the long barb on the right spicule. In contrast, the barb on the left spicule of $H$. okapiae is similar in size to the short barb and about $25 \%$ as long as the long barb of the right spicule. The dorsal ray of $H$. mitchelli is bifurcated distally for $25-39 \%(32 \%)$ of its length and its stem is expanded proximally, but the dorsal ray of $H$. okapiae is bifurcated $37-50 \%(42 \%)$ and its stem is of uniform thickness.
\end{abstract}

Species of Haemonchus Cobb, 1898, commonly referred to as large stomach worms, are significant pathogens of ruminants. They are among the most economically important parasites of cattle, sheep, and goats, causing significant production losses because of morbidity, mortality, cost of treatment, and suboptimal use of contaminated pastures (Gibbs and Herd, 1986). State of the art descriptions using the most sensitive character for identification of species, i.e., the pattern of surface cuticular ridges, the synlophe (Desset, 1964), is available for only 4 of the 12 species (Lichtenfels et al., 2001) of Haemonchus. A phylogenetic classification of the species is lacking. Modern descriptions of the remaining species and a predictive classification of the species of Haemonchus are the ultimate goals of the studies cited, and they would greatly improve the diagnosis and prospects for controlling these nematode pathogens worldwide.

A study of all available species of Haemonchus was undertaken to provide a further assessment of the synlophe and its usefulness for distinguishing among species and determining relationships within the genus. In the course of this study, significant new morphological information was discovered, including a unique modification of a common synlophe pattern, which allows the recognition of 2 species believed for more than $50 \mathrm{yr}$ to be synonymous. The objective of this paper is to present redescriptions of the 2 species Haemonchus mitchelli Le Roux, 1929, from the eland Taurotragus oryx and other African ruminants, and $H$. okapiae van den Berghe, 1937, known only from the okapi Okapia johnstoni.

\section{MATERIALS AND METHODS}

Specimens studied included 3 male and 3 female syntypes of $H$. mitchelli and 4 male and 4 female syntypes of $H$. okapiae. Ten specimens of each sex were measured. Measurements are in microns unless stated otherwise and are given as ranges followed by means in parentheses.

Nematodes were cleared in phenol-alcohol ( 80 parts melted phenol crystals and 20 parts absolute ethanol) for study in temporary wet

Received 14 December 2001; revised 28 March 2002; accepted 28 March 2002.

* Department of Pathology and Infectious Diseases, The Royal Veterinary College, University of London, North Mymms, Hatfield AL9 7TA, U.K. mounts on glass microscope slides. Interference-contrast light microscopy was used to study the synlophe and other characters at a magnification of $\times 200-400$. Some specimens were examined as temporary mounts in lactoglycerol to study the genital cone and bursa. Three specimens were dissected in Berlese's fluid, yielding a permanent mount to study the spicules and gubernaculum. Characteristics of the synlophe were studied in all cleared specimens. Cross sections were studied as freehand cuts made with a cataract knife and mounted in glycerine jelly. Drawings of the synlophe patterns were prepared freehand. Drawings of the characteristics of males were prepared with the aid of a camera lucida. Photomicrographs were obtained either with $35-\mathrm{mm}$ cameras using Kodak T-max 100 black and white film or Kodak Ektachrome 100, or with a Jenoptik ProgRes 3012 digital camera. Selected images on film were digitized with a Nikon Cool Scan III. Photomicrographs were prepared for presentation in Microsoft Powerpoint.

Measurements were made with a calibrated ocular micrometer. For determining the percentage of the body length covered by the synlophe, the prebursal body in males and the prevulvar body in females were considered to be $100 \%$, and the length of the synlophe is reported as a percentage of that portion of the body (Lichtenfels et al., 1986). Nematode taxa above genus level follow the system of Durette-Desset (1983). Statistical treatment of measurements was not done. Previous studies have shown that samples much larger than those available for this study are required (Lichtenfels et al., 1986, 1988; Jacquiet et al., 1997) to demonstrate significant size differences among species of Haemonchus.

Terminology for the synlophe follows Lichtenfels et al. (2001) and Lichtenfels and Pilitt (2000), except that 1 ridge on each side of the dorsal and ventral fields (previously counted as part of those fields) is now considered to be part of the lateral field. With this modification, the 26-ridge system of $H$. horaki Lichtenfels et al. (2001) has 6 ridges in each lateral field and 7 ridges in each of the dorsal and ventral fields. This change is proposed to correlate the position of the sublateral cords (Lichtenfels and Wergin, 1994) with the separation of lateral fields from dorsal and ventral fields.

\section{REDESCRIPTION}

\section{Haemonchus mitchelli Le Roux, 1929}

(Figs. 1-27)

With characters of genus. Synlophe extends from cephalic expansion over anterior $48 \%$ of prebursal or prevulvar body and consists of a maximum of 42 ridges (Figs. 1-6). Twentysix ridges at level of cephalic papillae (6 in each lateral field, 7 in each dorsal and ventral field). Ridges in each lateral field (Fig. 1) consist of paired lateral ridges, 2 no. 1 sublateral ridges and 2 slightly shorter border ridges that border dorsal and ventral limits of lateral fields. Slightly posterior to cervical papillae, 


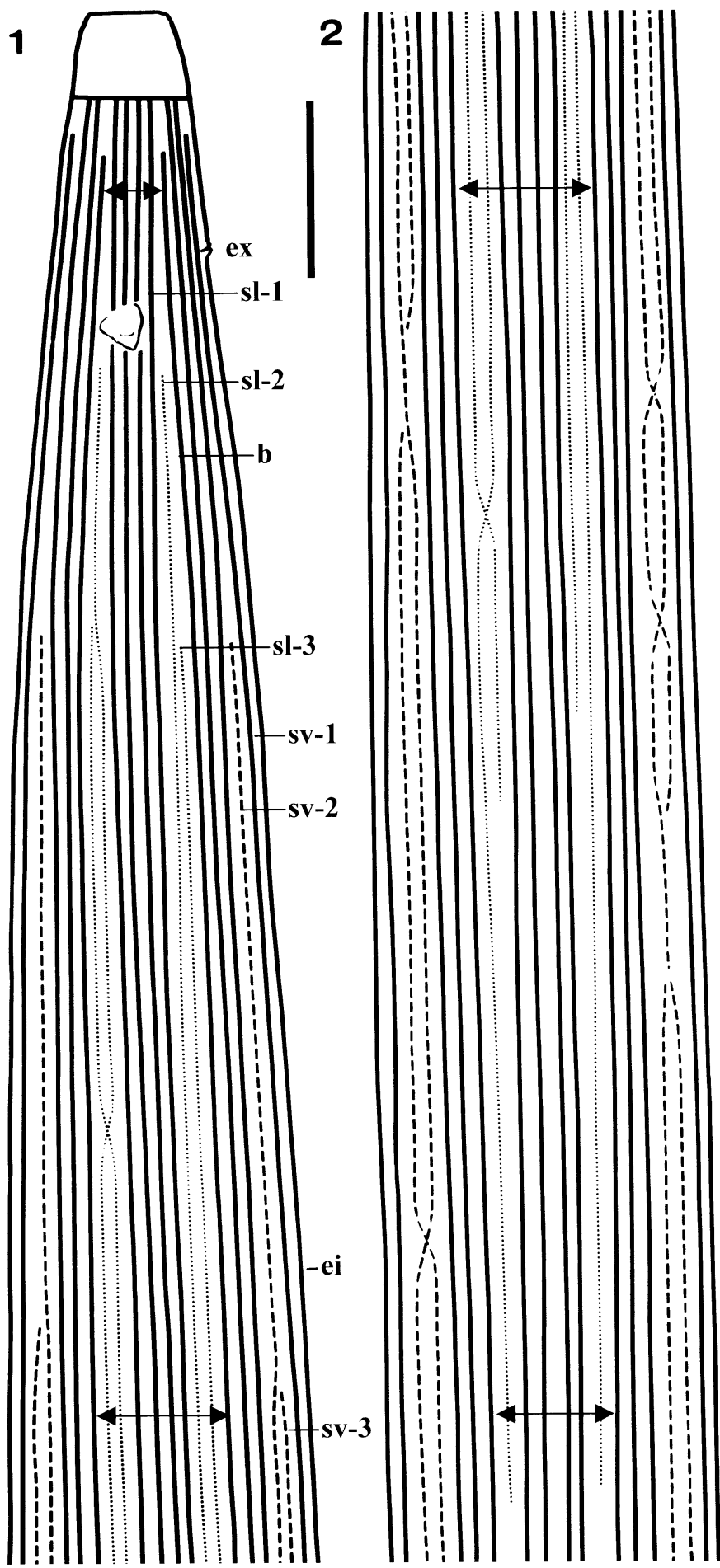

FIGURES 1-2. Haemonchus mitchelli, diagrammatic drawings, right lateral views of the synlophe (ex = excretory pore; ei = level of esophageal-intestinal junction). Scale bar $=200 \mu \mathrm{m}$. 1. Anterior end showing the distribution of the 6-10 ridges of each lateral field (double-headed arrows) and profile views of the 7-11 ridges of each dorsal and ventral field. Each lateral field includes (at level of cervical papilla) a pair of lateralmost ridges flanked by sublateral ridges 1 (sl-1), a pair of border ridges (b) that do not extend all the way to the cephalic expansion, and 4 additional sublateral ridges (dotted lines sl-2 and sl-3), which are added between sublateral ridges 1 and the border ridges. Each ventra field includes (anteriorly, in profile view) a ventral ridge, which is interrupted by the excretory pore, a slightly shorter subventral ridge (sv- between no. 1 sublaterals and border ridges, sublaterals no. 2 begin in each lateral field (1 dorsally and 1 ventrally) (Figs. 1, 9) and extend posteriorly for most of the length of synlophe, ending posteriorly dorsal or ventral to 4 lateralmost ridges, about $2.6 \mathrm{~mm}$ anterior to end of synlophe; sublaterals no. 3 begin next to each sublateral no. 2 ridge (lateral, dorsal, or ventral to it) near middle of esophagus (Figs. 1, 3) and extend to about $4.5 \mathrm{~mm}$ anterior to end of synlophe (Figs. 1, 4). Because of crossovers, distinguishing between sublateral no. 2 and no. 3 ridges may be impossible, but the posterior ends of sublaterals 2 and 3 are always dorsal or ventral to sublaterals no. 1 (Figs. 2, 4).

Dorsal and ventral fields with single dorsal or ventral ridges (in contrast to paired lateral ridges of lateral fields). Ventral ridge in line with excretory pore. Subventral ridges 1 flank each side of ventral ridge (Fig. 1 shows only right subventrals and ventral ridges). Subventral ridges no. 2 begin bilaterally, adjacent to subventral 1 , at level of midesophagus and extend to end of synlophe. Subventral ridges no. 3 begin bilaterally parallel to subventral ridges no. 2 , at or slightly posterior to the junction of esophagus and intestine and end within $1.5 \mathrm{~mm}$ of end of synlophe. Ridges of the dorsal field arranged in a similar pattern as those in ventral field.

Male (3 syntypes and 7 voucher specimens from type host): Body length 11.0-16.3 mm (13.9 mm). Esophagus length 1.28$1.48 \mathrm{~mm}(1.40 \mathrm{~mm}) ; 8.6-13.2 \%(10.0 \%)$ of body length. Anterior end to nerve ring 200-300 (260); to excretory pore 195325 (283) (Figs. 1, 8); to cervical papillae 200-420 (376) (Figs. $1,9)$; to subventral esophageal gland duct orifices (SVGO) 475-575 (542) (Fig. 8). Spicule length 520-575 (540); right spicule with 2 barbs, short expansion of distal tip forms short barb 20-35 (24), second barb 75-92 (85) from tip, left spicule with single barb continuous with distal tip 35-45 (39) from tip (Figs. 16, 19). Gubernaculum 310-355 (335) long (Figs. 12, $21)$, spindle-shaped in dorsal view in anterior half but with narrower posterior half. Dorsal ray 140-165 (154), divided for 25$39 \%(32 \%)$ of its length (Figs. 15, 17); branches 40-60 (49) long. Genital cone with single ventral "0" papilla (Figs. 14, 18), paired lateral genital appendages with membranous supports (Figs. 14, 18), and paired dorsal "7" papillae as long as lateral genital appendages (Figs. 14, 18). Synlophe ends distally at $45-52 \%(48 \%)$ of prebursal body length.

Female (3 syntypes and 7 specimens from the type host): Body length $17.8-22.7 \mathrm{~mm}(20.5 \mathrm{~mm})$. Esophagus length 1.51$1.75 \mathrm{~mm}(1.58 \mathrm{~mm}), 7.0-8.6 \%(7.8 \%)$ of body length. Anterior end to nerve ring 205-290 (266); to excretory pore 225-330 (289); to cervical papillae 325-440 (402); to SVGO 550-700 (639). Vulva with or without knobs or vulval flap or lobe (or both) (Fig. 25); located posteriorly $81-85 \%$ (83\%) of body length. Vagina length 100-150 (122). Ovejector (Fig. 25) welldeveloped posteriorly and anteriorly, consisting of distinct parts

1), 2 ridges that extend the full length of the synlophe, and additional shorter ridges (dotted lines sv-2 and sv-3), which are added lateral to sv-1. The left lateral view (not shown) approximates a mirror image of the right lateral view. 2. Postesophageal region (continuous with Fig. 1) showing the posterior ends of sublateral ridges 2 and 3 (dotted lines), and examples of crossovers and anastomoses typical of the subventral, subdorsal, and sublateral ridges. 


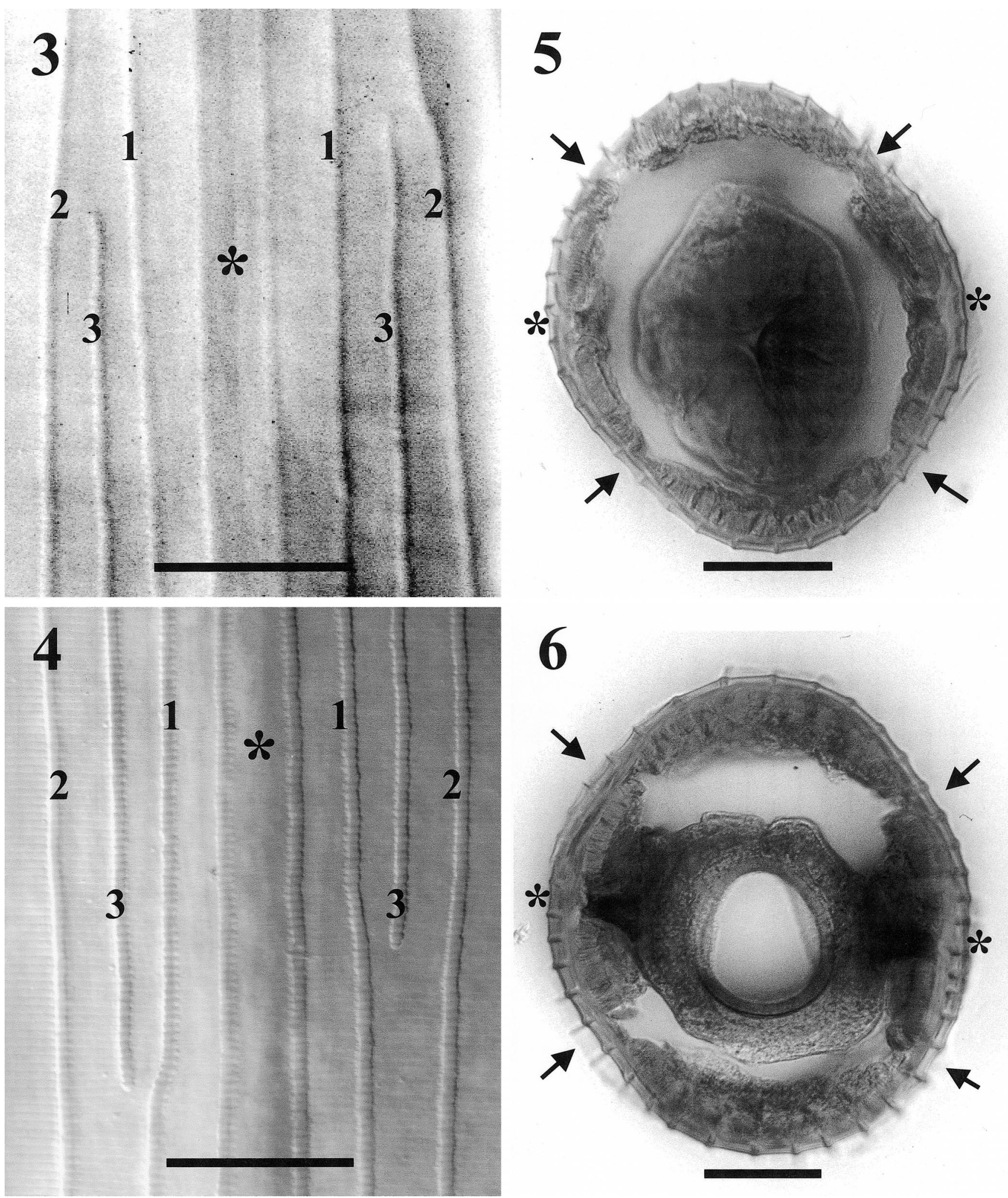

FIGURES 3-6. Haemonchus mitchelli, photomicrographs of characteristics of synlophe. (* = lateral; numbers label sublateral ridges 1, 2, and 3; arrows at sublateral hypodermal cords). Scale bars $50 \mu \mathrm{m}$. 3. Lateral synlophe of male in region anterior to midesophagus, showing anterior ends of sublateral ridges no. 3, between sublateral ridges nos. 1 and 2. 4. Lateral synlophe of female, about $2.6 \mathrm{~mm}$ from anterior end, showing posterior ends of sublateral ridges no. 3. 5. Cross section of male through the mid-esophagus (region shown in Fig. 3 ), showing 10 ridges in each lateral field (between arrows), 9 ridges in the ventral field, and 9 in the dorsal field. Only 38 ridges are present because the no. 3 subventrals and subdorsals begin posterior to this level, near the level of the esophageal-intestinal junction (see Fig. 1). 6. Cross section of male through intestine about $2 \mathrm{~mm}$ from anterior end showing 41 of the 42 ridges usually present in this region, including 10 ridges in each lateral field, 10 in the dorsal field, and 11 in the ventral field. 


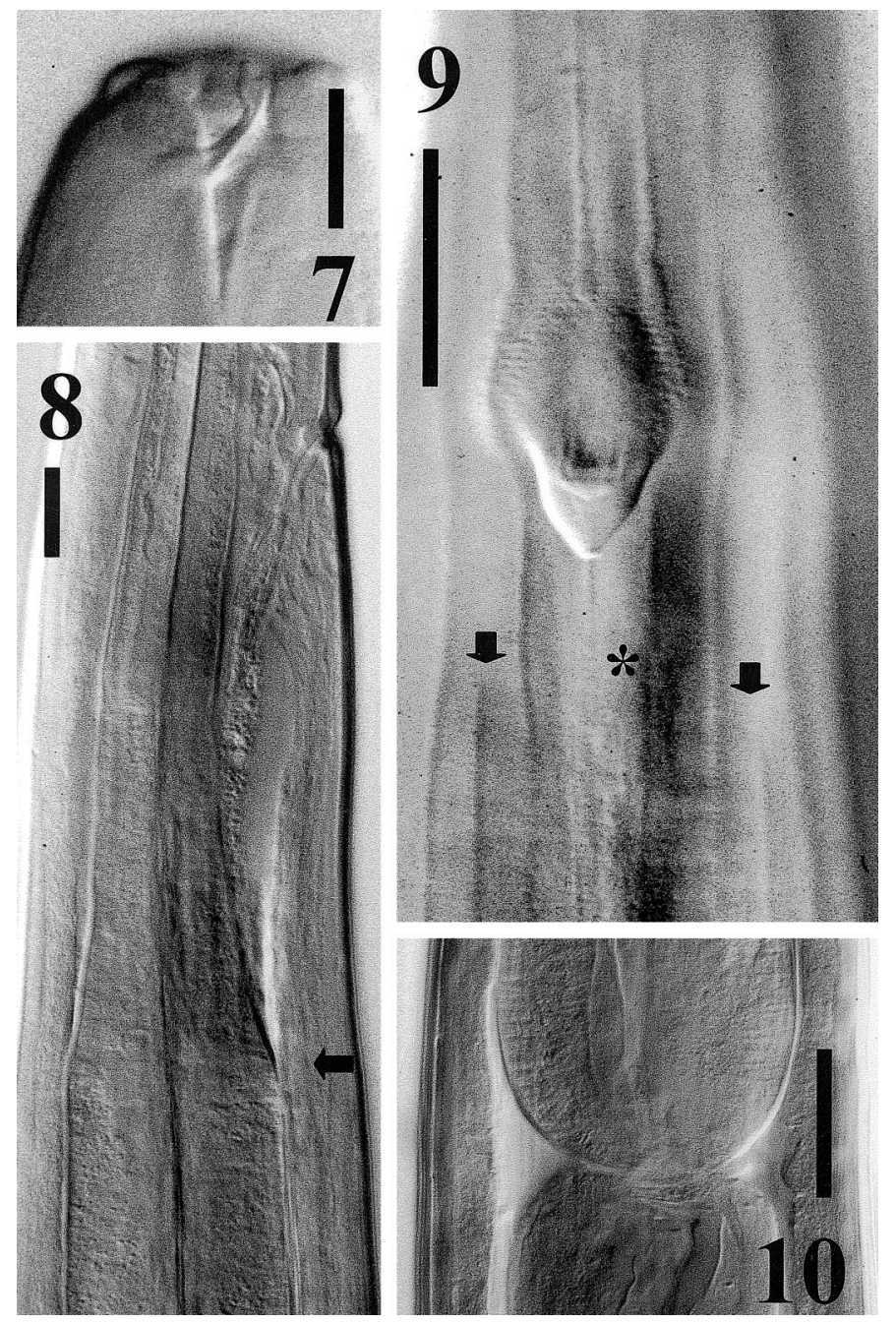

FIGURES 7-10. Haemonchus mitchelli, photomicrographs of head and esophageal region. 7. Head of male, right lateral view, showing dorsal buccal tooth. Scale bar $=10 \mu \mathrm{m}$. 8. Cervical region, right lateral view, showing excretory pore with ring thickening in duct at the pore and separation (SVGO) of anterior muscular esophagus and posterior more glandular esophagus (arrow). Scale bar $=50 \mu \mathrm{m}$. 9. Surface view of right cervical papilla and synlophe showing anterior ends of sublateral ridges no. 2 (arrows) $(*=$ lateral). Scale bar $=50 \mu \mathrm{m}$. 10. Esophageal-intestinal junction, right lateral view. Scale bar $=50 \mu \mathrm{m}$.

(lengths): vestibule 155-200 (181); anterior sphincter 200-270 (216); anterior infundibulum 275-460 (364); posterior sphincter 165-260 (206); posterior infundibulum 225-425 (351). Eggs in uterus 63-80 (69) by 40-45 (42) (Fig. 23). Perivulval pore (Figs. 26, 27) in cuticle, dorsolaterally on each side at level of posterior infundibulum 600-1,000 (800) posterior to vulva. Tail tapers gradually 280-400 (354) long (Fig. 24); phasmids dorsolaterally 65-125 (100) from tip. Synlophe ends posteriorly anterior to midbody $41-57 \%$ (48\%) of prevulvar body length.

\section{Taxonomic summary}

Type host: Common eland Taurotragus oryx Pallas (Bovidae: Bovinae: Tragelaphini).

Site of infection: Abomasum.
Type locality: Drakensberg National Game Reserve, Natal, South Africa.

Prevalence and intensity: "Heavy" infection reported in type host (Le Roux, 1929).

Specimens studied: Syntypes, British Museum of Natural History, London, U.K., British Museum of Natural History no. 1998.19.27-41, 3 males and 3 females (of these, 1 male designated lectotype, 1 female designated allolectotype, 2 males and 2 females designated paralectotypes); from the type host collected in 1980 in Mountain Zebra National Park, Eastern Cape Province, South Africa $\left(32^{\circ} 15^{\prime} \mathrm{S}, 25^{\circ} 27^{\prime} \mathrm{E}\right), 8$ males and 8 females; U.S. National Parasite Collection (USNPC), Beltsville, Maryland 20705-2350, USNPC no. 87597.

\section{REDESCRIPTION}

\section{Haemonchus okapiae van den Berghe, 1937}

(Figs. 28-49)

With characters of genus. Synlophe of 42 ridges extends posteriorly from cephalic expansion over anterior $33 \%$ of prebursal or prevulvar body length. Distribution of ridges in $H$. okapiae as in $H$. mitchelli except for shorter pattern in H. okapiae.

Male (4 syntypes and 6 voucher specimens from type host): Body length 12.6-17.3 mm (15.1 mm). Esophagus length $1.25-1.58 \mathrm{~mm}(1.43 \mathrm{~mm}) ; 8.2-11.4 \%(9.6 \%)$ of body length. Anterior end to nerve ring 215-320 (273); to excretory pore 225-350 (294) (Fig. 30); to cervical papillae 300-450 (390) (Fig. 31); to SVGO 510-590 (577) (Fig. 31). Spicule length 455-490 (479); short barb formed by expansion of distal foot pad at end of each spicule, short barbs of right and left spicules nearly equal in length 15-20 (16) in ventral view (Fig. 39) but with short barb of right spicule slightly longer in dorsolateral view (Figs. 42, 43); right spicule also bears lateral barb 60-75 (67) from distal tip (Figs. 39, 42). Gubernaculum 275-310 (289) long (Figs. 34, 44), spindle-shaped in dorsal view. Dorsal ray 130-150 (137), divided for $37-50 \%(42 \%)$ of its length (Figs. 38, 40); bifurcation 50-70 (58) deep. Genital cone with single ventral " 0 " papilla, paired lateral, fingerlike genital appendages with membranous supports (Figs. 36,41 ) and paired, short, rounded dorsal "7" papillae (Figs. $37,41)$. Synlophe ends distally at 30-37\% (33\%) of prebursal body length.

Female (4 syntypes and 6 specimens from the type host): Body length 21.3-25.9 mm (23.6 mm). Esophagus length 1.43$1.75 \mathrm{~mm}(1.57 \mathrm{~mm}), 6.3-7.2 \%(6.6 \%)$ of body length. Anterior end to nerve ring 250-335 (279); to excretory pore 275-310 (300); to cervical papillae 320-450 (400); to SVGO 550-725 (626). Vulva with or without knobs or vulval flap or lobe (or both) (Fig. 48); located posteriorly $81-84 \%$ (83\%) of body length. Vagina length 120-160 (133). Ovejector (Figs. 48, 49) well-developed posteriorly and anteriorly, consisting of distinct parts (lengths): vestibule 205-260 (229); anterior sphincter 175-280 (229); anterior infundibulum 315-480 (402); posterior sphincter 180-300 (233); posterior infundibulum 325-485 (410). Eggs in uterus 73-86 (80) by 34-45 (43) (Fig. 47). Perivulval pore in cuticle, dorsolaterally on each side at level of posterior infundibulum. Tail tapers gradually 270-350 (312) long (Fig. 46); phasmids dorsolaterally 60-100 (85) from tip. Synlophe ends posteriorly at $32-43 \%$ (39\%) of prevulvar body length. 

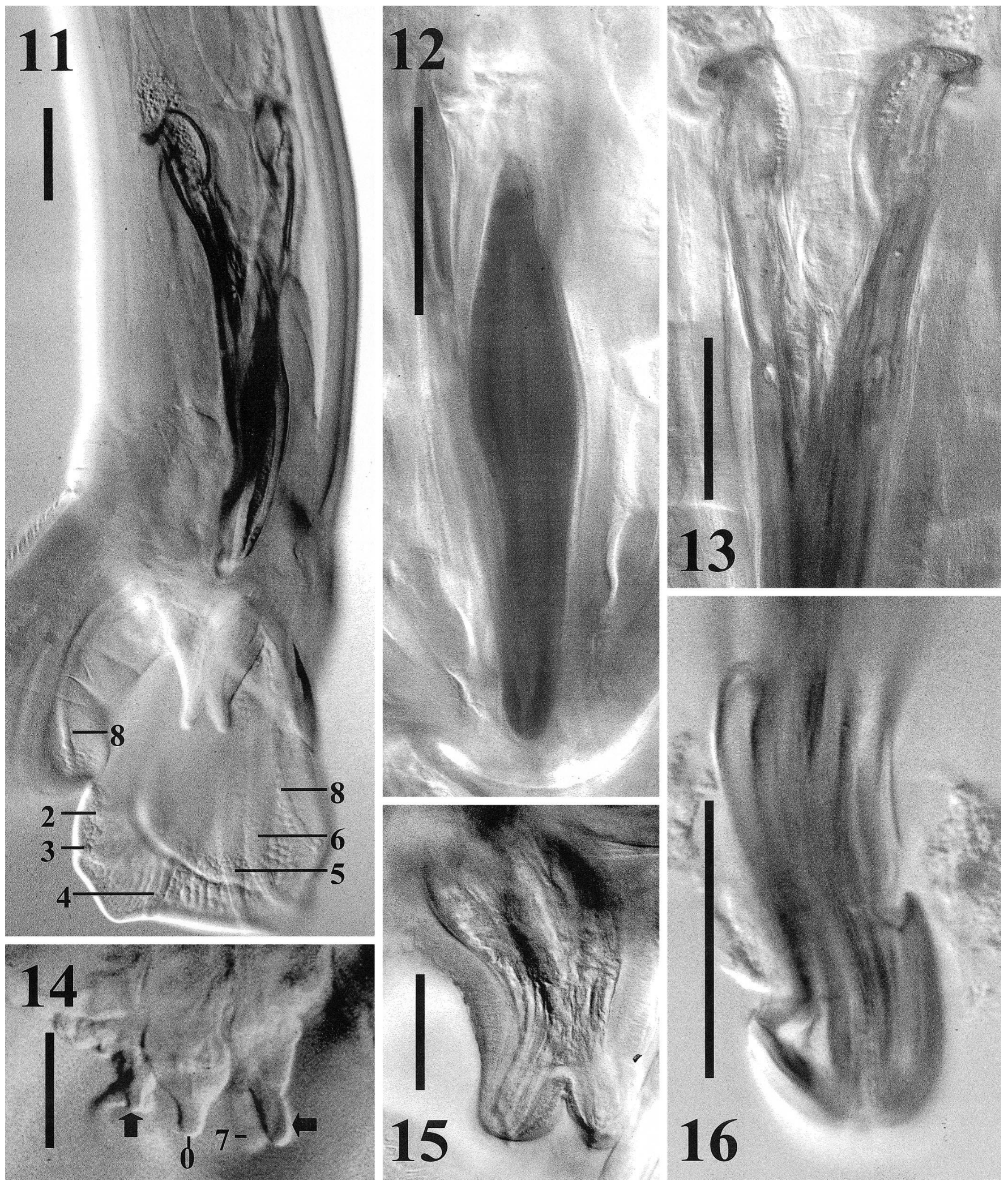

FIGURES 11-16. Haemonchus mitchelli, photomicrographs of male characteristics. 11. Spicules, gubernaculum, and copulatory bursa, subventral view, showing relative sizes of structures and disposition of rays 2-6 and 8 of left bursal lobe, ray 8 of right bursal lobe, and bifurcated dorsal ray. Scale bar $=100 \mu \mathrm{m}$. 12. Gubernaculum, dorsal view. Scale bar $=100 \mu \mathrm{m}$. 13. Proximal half of spicules, ventral view. Scale bar $=100 \mu \mathrm{m}$ 14. Genital cone, ventral view, showing single ventral " 0 " papilla (0), portions of lateral appendages and supporting membranes (solid arrows), and one of the paired, dorsal no. 7 papillae (7). Scale bar $=50 \mu \mathrm{m}$. 15. Dorsal ray, dorsal view. Scale bar $=50 \mu \mathrm{m}$. 16. Spicule tips, ventral view. Scale bar $=50 \mu \mathrm{m}$. 


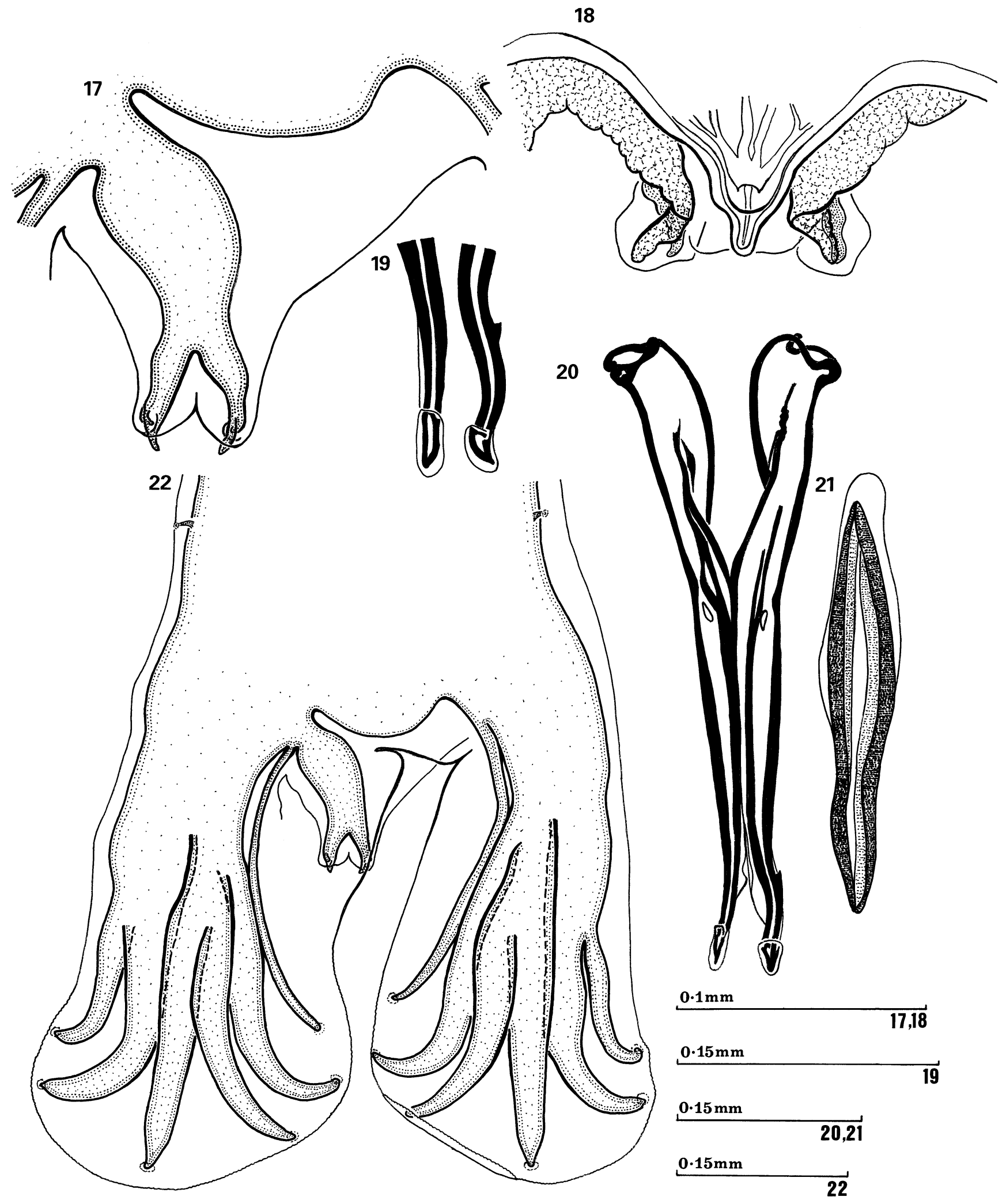

FIGURES 17-22. Haemonchus mitchelli, line drawings of male characteristics. 17. Dorsal lobe of bursa, dorsal view. 18. Composite figure of genital cone, ventral view. 19. Distal tips of spicules, dissected out of body, dorsal view. 20. Spicules, dissected out of body, dorsal view. 21. Gubernaculum, dorsal view. 22. Copulatory bursa, dorsal view. 

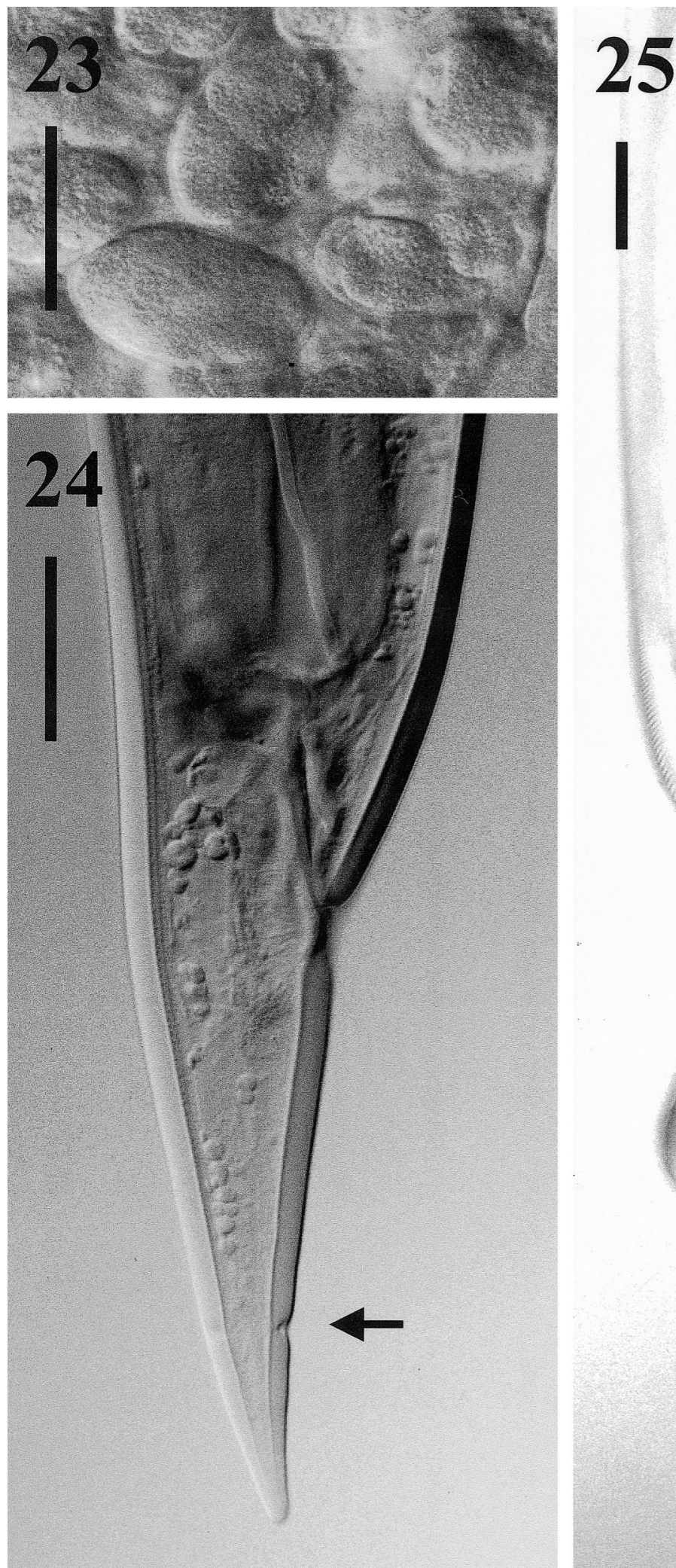

5
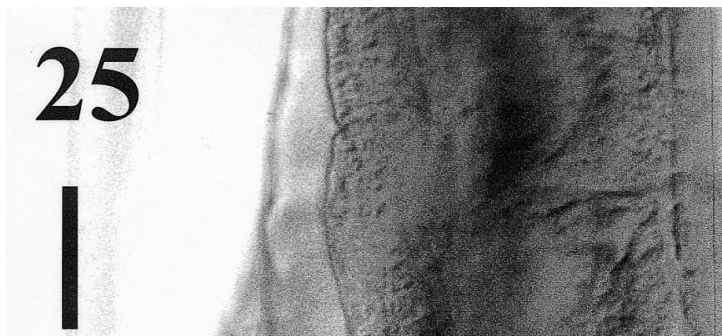

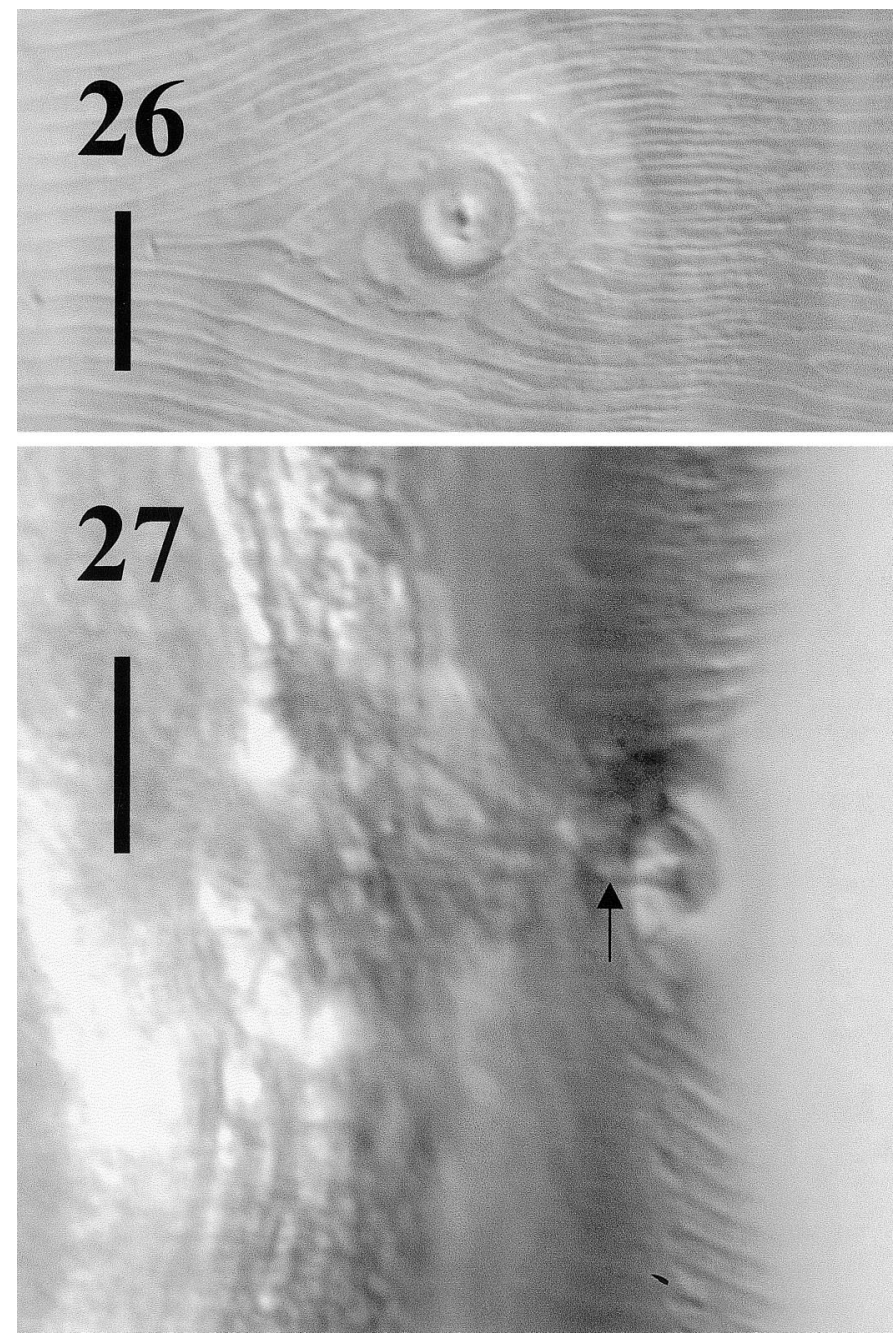

FIGURES 26-27. Haemonchus mitchelli, photomicrographs of perivulval pores. Scale bars $10 \mu \mathrm{m}$. 26. Surface view. 27. Optical section showing duct (arrow) extending into lateral cord.

\section{Taxonomic summary}

Type host: Okapi Okapia johnstoni (Sclater) (Giraffidae). Site of infection: Abomasum.

Type locality: Epulu River, Ituri District, Zaire.

Prevalence and intensity: Unknown.

Specimens studied: Syntypes, USNPC nos. 61418 (van den Berghe, 1937; okapi no. 129) and 61420 (okapi no. 88) and Museum of Comparative Zoology (MCZ; Harvard University, Cambridge, Massachusetts) no. 702N (okapi no. 72). One male syntype from USNPC no. 61418 designated lectotype and given new USNPC no. 92382; 1 female syntype from USNPC no. 61418 designated allolectotype and given new USNPC no. 92383; all remaining syntypes designated paralectotypes, original collection numbers retained; additional, voucher specimens from the type host and type locality USNPC no. 61419 and MCZ no. 703N (okapi no. 112), MCZ nos. 700N (okapi nno. 130), $701 \mathrm{~N}$ (captive okapi), and 704N (okapi no. 109). In MCZ nos. $701 \mathrm{~N}$ and $703 \mathrm{~N}$, in addition to $H$. okapi, specimens of $H$. lawrencei Sandground, 1933, were present.

\section{Diagnosis}

Both male and female $H$. mitchelli can be distinguished from all other species of the genus by their unique synlophe (except H. vegliai Le Roux, 1929, for which detailed characteristics of the synlophe are undetermined). Among Haemonchus spp., a 42-ridge synlophe has been observed only in $H$. mitchelli, $H$. okapiae, H. longistipes Railliet and Henry, 1909, and, tentatively, $H$. vegliai. The presence of a 42-ridge synlophe can be determined by finding and identifying 1 or more of the sublateral no. 3 ridges and 1 or more subventral or subdorsal no. 2 ridges. Because of the symmetry of the synlophe, it is not necessary to find the marker ridges in all areas of the nematode when correlating characters are present. Including $H$. vegliai in this group is tentative, because a preliminary study of the synlophe of this species has found variation similar to that seen in experimental hybrids (J. R. Lichtenfels, unpubl. data) in the presence of sublateral ridges no. 3 and subventral and subdorsal ridges no. 2. Additional lots of $H$. vegliai must be studied to determine whether it has a 42-ridge synlophe, a 34-ridge synlophe, or something in between. The synlophes of 3 species, $H$. mitchelli, $H$. okapiae, and $H$. longistipes, consist of 42 ridges distributed over the anterior half of the body. The 3 species with a 42-ridge synlophe can be separated by unique structural characteristics of their synlophes, spicules, and copulatory bursa.

The species most similar to H. mitchelli is H. okapiae, but the 2 species can be distinguished by differences in the length of the synlophe and the structure of the spicules and dorsal ray. In $H$. mitchelli, the synlophe covers $45-52 \%$ (48\%) of the prebursal body of males, or $41-57 \%$ (48\%) of the prevulvar body of females. The synlophe of $H$. okapiae is very similar to that of $H$. mitchelli, but it is significantly shorter (distributed over the anterior $30-37 \%$ (33\%) of the prebursal body or $32-$ $43 \%(39 \%)$ of prevulvar body). The distal tip of the left spicule of $H$. mitchelli bears a barb that is almost twice as long as the short barb and about half as long as the long barb on the right spicule (Figs. 16, 19). In contrast the barb on the left spicule of $H$. okapiae is similar in size to the short barb and is about $25 \%$ as long as the long barb of the right spicule (Figs. 39, 42). The dorsal ray of $H$. mitchelli is bifurcated distally for about $32 \%$ of its length and its stem is expanded proximally (Figs. 15, 17), but the dorsal ray of $H$. okapiae is bifurcated for about $42 \%$ and its stem is of uniform thickness (Figs. 38, 40).

Haemonchus longistipes can be distinguished by the characteristics of the spicules and synlophe. Males of $H$. longistipes have long spicules (484-684), with single barbs near distal tips at 85-108 (right) and 28-42 (left) (Gibbons, 1979). The synlophe of both male and female $H$. longistipes can be distinguished by sublateral ridges no. 2 that extend anterior to the cervical papillae and subventral ridges no. 1, which usually begin near the excretory pore (J. R. Lichtenfels, unpubl. data).

The spicules of $H$. vegliai are distinctive (Gibbons, 1979), 461-517 long, with the distal tip of the left one curved ventrally and bearing 2 prominent barbs $34-48$ and $49-63$ from the tip and the right one bearing 1 barb $68-84$ from the tip. 

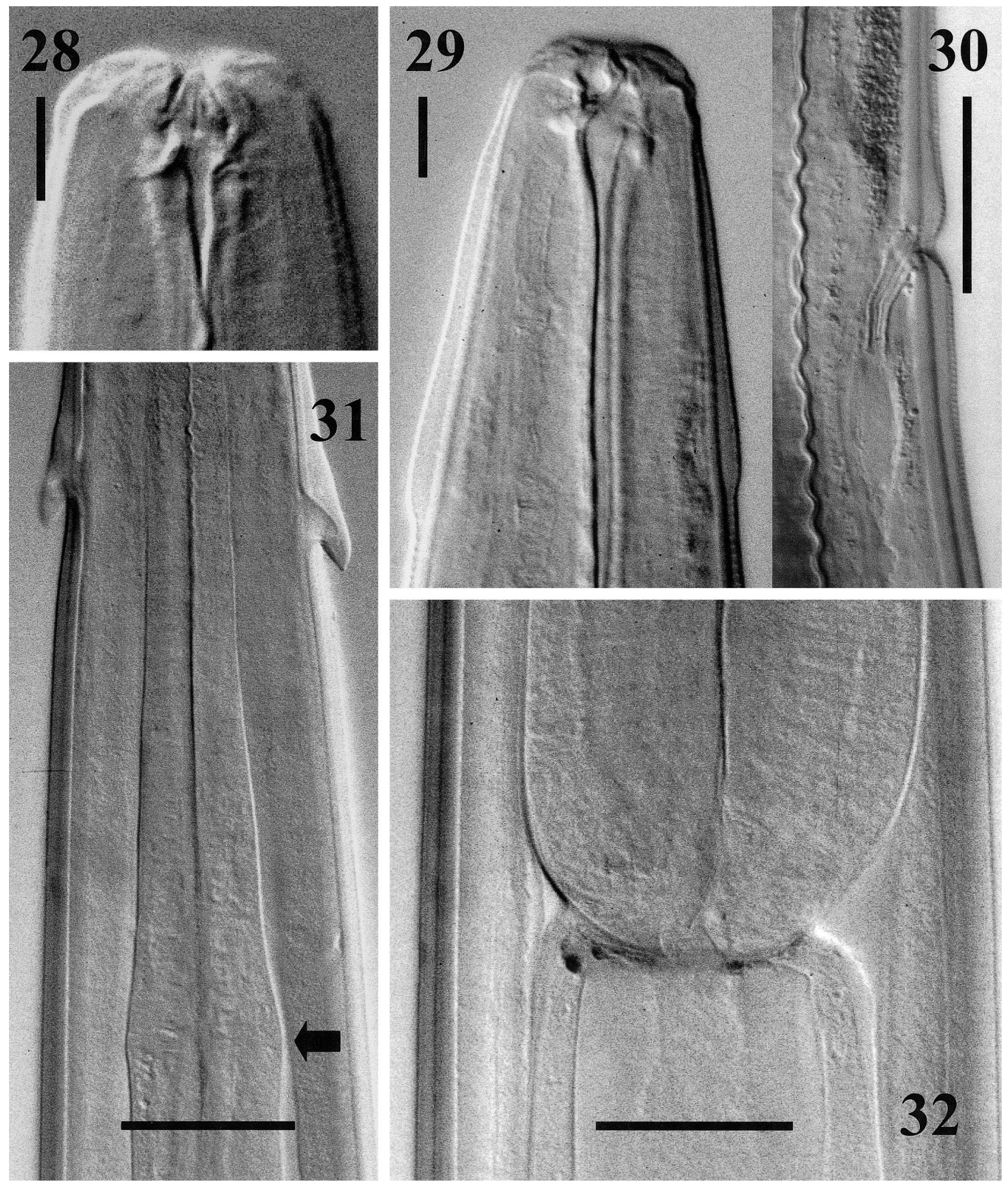

FIGURES 28-32. Haemonchus okapiae, photomicrographs of head and esophageal region of paralectotypes. 28. Head of male, ventral view, showing dorsal buccal tooth with terminal pore of duct of dorsal esophageal gland. Scale bar $=10 \mu \mathrm{m}$. 29. Head of male, right, lateral view, showing large dorsal buccal tooth and cephalic expansion. Scale bar $=10 \mu \mathrm{m}$. 30. Excretory pore of male, lateral view. Scale bar $=50 \mu \mathrm{m}$. 31 . Cervical region of male, ventral view, showing paired lateral cervical papillae, and separation (SVGO) of anterior muscular esophagus and posterior more glandular esophagus (arrow). Scale bar $=50 \mu \mathrm{m}$. 32. Esophageal-intestinal junction of male, ventral view. Scale bar $=50 \mu \mathrm{m}$. 

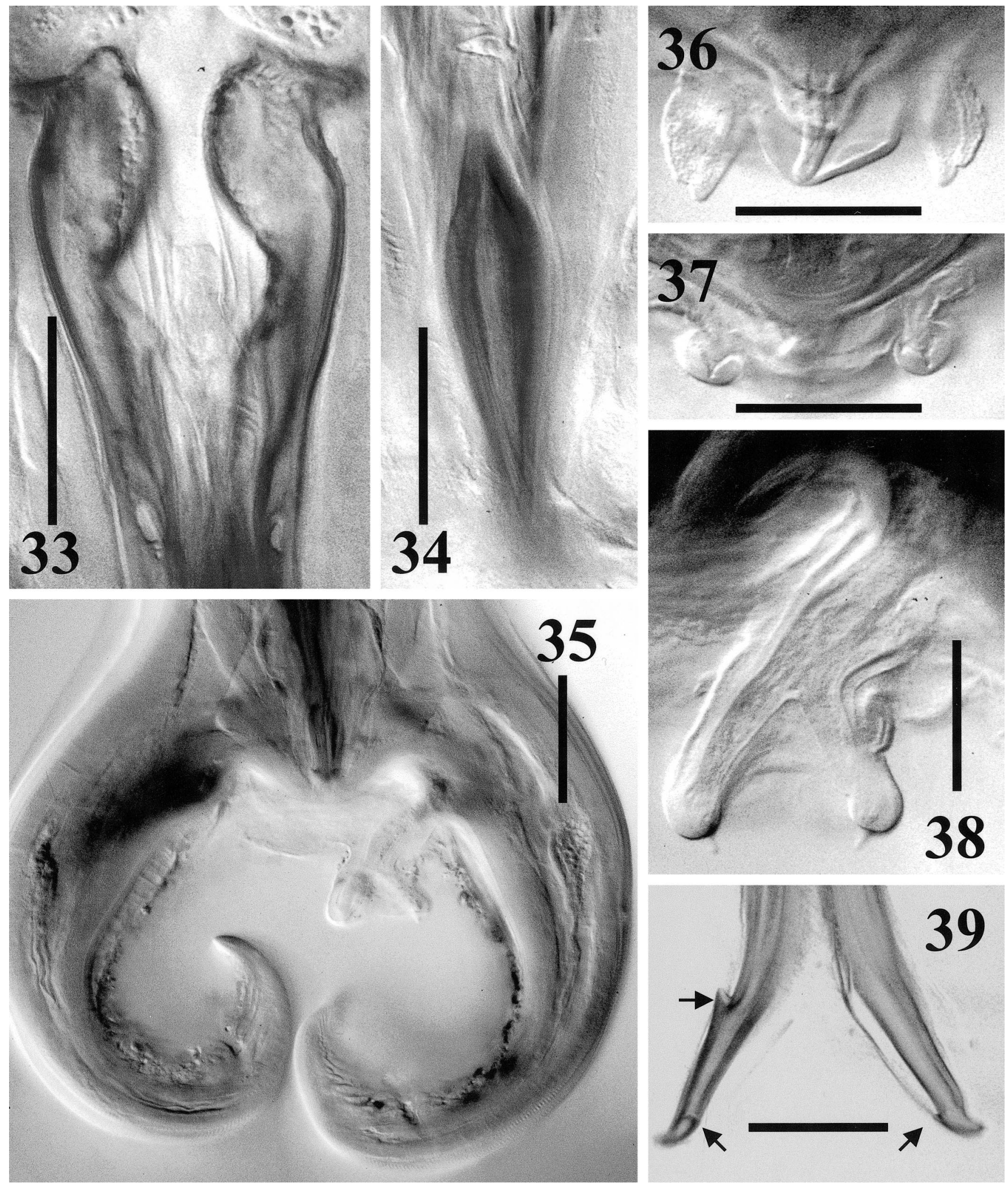

FIGURES 33-39. Haemonchus okapiae, photomicrographs of male characteristics (all, except Fig. 39, of paralectotypes). 33. Proximal half of spicules, ventral view. Scale bar $=100 \mu \mathrm{m}$. 34. Gubernaculum, dorsal view. Scale bar $=100 \mu \mathrm{m}$. 35. Copulatory bursa, ventral view, showing relative sizes of dorsal and lateral rays. Scale bar $=100 \mu \mathrm{m}$. 36. Genital cone, ventral view, showing single ventral " 0 " papilla and lateral appendages and supporting membranes. Scale bar $=50 \mu \mathrm{m}$. 37. Genital cone, ventral view, showing paired, dorsal, short, rounded papillae no. 7. Scale bar $=50 \mu \mathrm{m}$. 38. Dorsal ray, ventral view. Scale bar $=50 \mu \mathrm{m}$. 39. Distal spicule tips, ventral view, showing short dorsal barbs at tips of both spicules (lower arrows) and lateral barb on right spicule (upper arrow) more distant from the tip. Scale bar $=100 \mu \mathrm{m}$. 

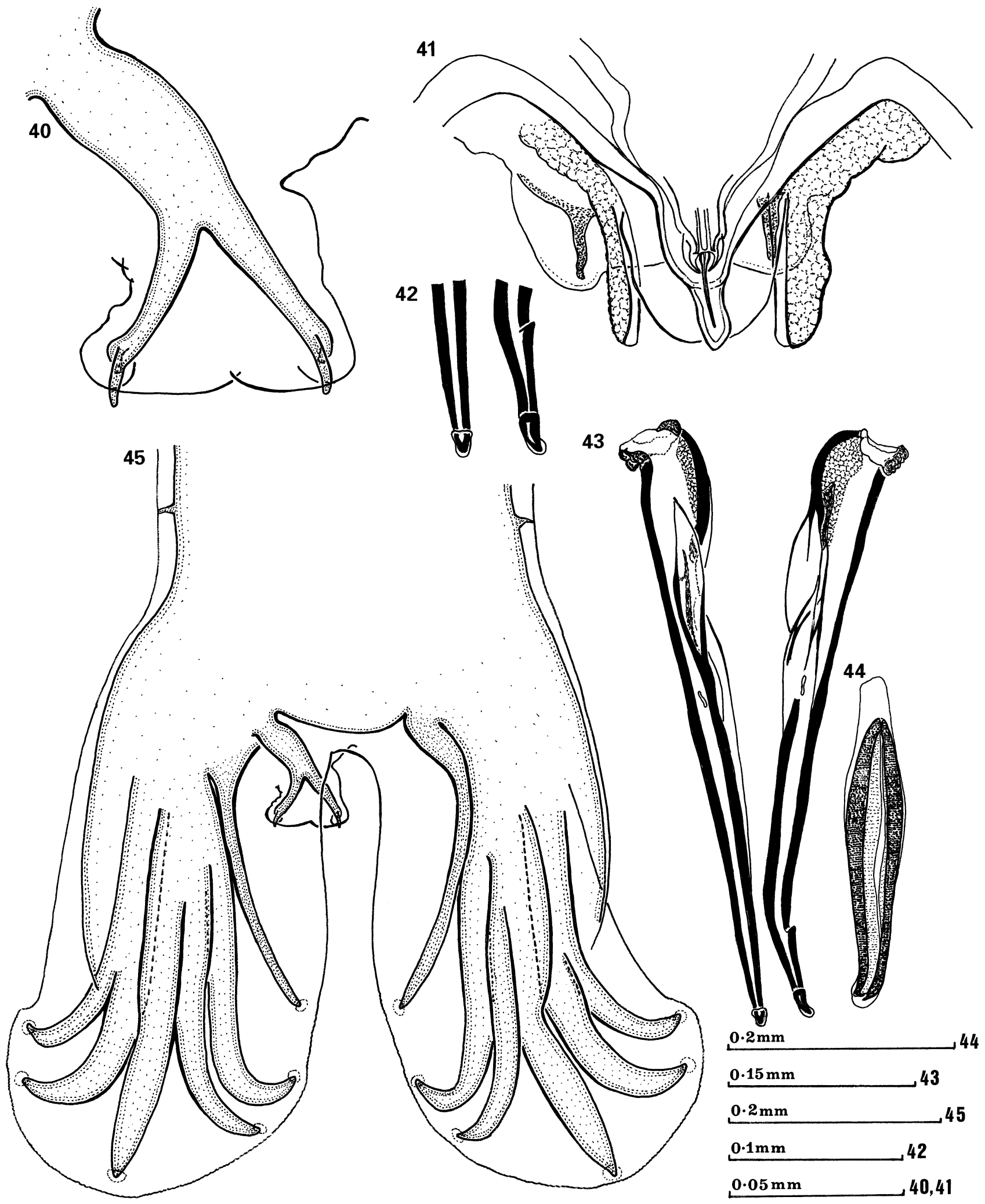

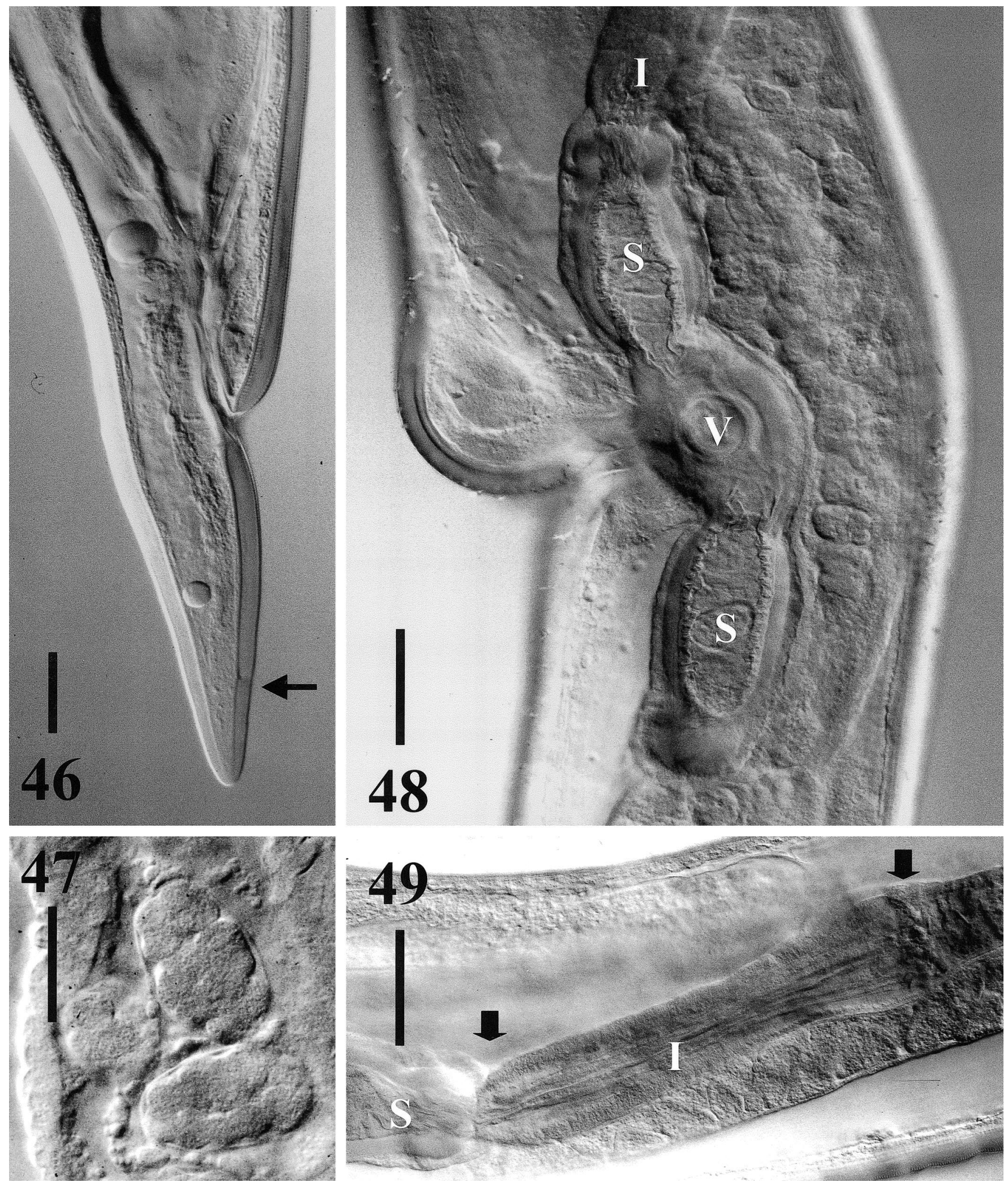

FIGURES 46-49. Haemonchus okapiae, photomicrographs of female characteristics. 46. Tail, lateral view, showing anus and one of the paired phasmids (arrow). Scale bar $=100 \mu \mathrm{m}$. 47. Uterine eggs. Scale bar $=50 \mu \mathrm{m}$. 48. Ovejectors, lateral view, showing vestibule (V) and anterior and posterior sphincters $(\mathrm{S})$. I $=$ infundibulum. Scale bar $=100 \mu \mathrm{m}$. 49. Posterior infundibulum (I) between arrows, lateral view. Scale bar $=$ $100 \mu \mathrm{m}$. 


\section{DISCUSSION}

Previous studies of $H$. mitchelli and $H$. okapiae have usually resulted in the latter being considered a synonym of the former. This was partly because of the lack of available specimens of $H$. okapiae and the apparent loss of the syntypes (Gibbons, 1979). The description of $H$. okapiae by van den Berghe (1937) was accurate and adequate for separating males from $H$. mitchelli. But it was inadequate for distinguishing $H$. okapiae from other species such as $H$. contortus (Rudolphi, 1803), with which Baer (1950) synonymized it, without having type specimens available. In her revision of Haemonchus spp., Gibbons (1979) also failed to find the syntypes of $H$. okapiae but studied specimens from the type host and locality obtained from the MCZ and concluded that the material was a mixture of $H$. mitchelli and $H$. contortus. Thus, she considered $H$. okapiae to be synonymous, in part, with $H$. mitchelli and accepted Baer's (1950) synonomy with $H$. contortus. It was fortunate to find the syntypes of $H$. okapiae (2 lots in the USNPC and 1 lot in the MCZ). Characteristics of the synlophe, spicules, and dorsal ray were sufficient to distinguish both males and females of $H$. okapiae from related species. The specimens from MCZ were restudied and found to be a mixture of species, including $H$. okapiae, H. lawrencei, and perhaps other species because not all specimens were examined on account of their poor condition.

Previous studies described a synlophe pattern common to species of the Haemonchinae, with variation in number of ridges among species consisting of the addition of ridges in specific sublateral or subdorsal and subventral regions of the synlophe (Lichtenfels and Pilitt, 2000; Lichtenfels et al., 2001). Three different synlophe patterns, based on number of ridges, have been reported (Lichtenfels et al., 2001) to occur among species of Haemonchus, including those with (1) 26 ridges (H. horaki, H. dinniki Sachs et al., 1973, and H. lawrencei); (2) 30 ridges, including 4 additional sublateral ridges, $(H$. contortus and $H$. krugeri Ortlepp, 1964) (Lichtenfels et al., 1994, 2001); and (3) 34 or more ridges, including an additional 2 subventral and 2 subdorsal ridges, (those with 34 ridges include $H$. placei (Place, 1893), H. similis Travassos, 1914, and H. bedfordi Le Roux, 1929) (Lichtenfels et al., 1994; Lichtenfels, unpubl.). A fourth pattern, with 42 ridges, described here for $H$. mitchelli and $H$. okapiae, was not described before the present study, but it fits the pattern described by Lichtenfels and Pilitt (2000). In the 42ridge synlophe the 4 no. 2 sublaterals, 2 subventral ridges, and 2 subdorsal ridges present in the 34-ridge synlophe are all duplicated, resulting in an additional 8 ridges. The additional 8 ridges (no. 3 sublaterals and no. 2 subventrals and subdorsals) are shorter and located more posteriorly than the no. 2 sublaterals or no. 1 subventrals and subdorsals. A similar 42-ridge system is present (J. R. Lichtenfels, unpubl. data) in H. longistipes and may be present in $H$. vegliai, but additional lots of specimens are needed to confirm this preliminary observation (J. R. Lichtenfels, unpubl. data).

The information presented here provides morphological characteristics for the recognition of large stomach worms of the okapi as a separate species as proposed by van den Berghe (1937). The okapi is the only known host of $\mathrm{H}$. okapiae. It was recovered from 7 individual okapi in moderate numbers (van den Berghe, 1937) and is considered to be a normal parasite of that host. One additional lot, found in the USNPC, was identified by M. B. Chitwood as H. okapiae. It was collected from an okapi that was imported into the United States from Germany in 1961. This identification was confirmed, providing additional evidence that the okapi is a normal host of this species.

It is interesting to speculate that if $H$. okapiae is a normal parasite of the okapi, it may also be a parasite of the related giraffe. Because $H$. okapiae was considered to be a synonym of $H$. mitchelli for more than $50 \mathrm{yr}$, specimens identified as $H$. mitchelli from giraffes should be reexamined, for example, Ortlepp (1961), Sachs et al. (1973), and Krecek et al. (1990). Other species of Haemonchus have been reported from the giraffe (Sachs et al., 1973) as well as from the okapi, and the host specificity of Haemonchus spp. apparently is not strong. But studies by Le Jambre (1983) and Amarante et al. (1997) have shown that, although $H$. placei and $H$. contortus occur naturally in a variety of ruminants, each species is better adapted to its primary host and can replace competitors in that host.

\section{LITERATURE CITED}

Amarante, A. F. T., J. Bagnola Jr., M. R. V. Amarante, and M. A. BARbosA. 1997. Host specificity of sheep and cattle nematodes in Sao Paulo State, Brazil. Veterinary Parasitology 73: 89-104.

BAER, J. G. 1950. Etude critique des helminthes parasites de l'Okapi. Acta Tropica 1: 164-186.

Desset, M. C. 1964. Les systemes d'aretes cuticularies chez les Nematodes Heligmosomes. Etude de cinq especes parasites de Rongeurs de la Maboke. Cahiers de la Maboke 2: 39-78.

Durette-Desset, M. C. 1983. Keys to genera of the superfamily Trichostrongyloidea. In $\mathrm{CIH}$ Keys to the nematode parasites of vertebrates, R. C. Anderson, and A. C. Chabaud (eds.). Commonwealth Agricultural Bureaux, Farnham Royal, U.K., 68 p.

Gibbons, L. M. 1979. Revision of the genus Haemonchus Cobb, 1898 (Nematoda: Trichostrongylidae). Systematic Parasitology 1: 3-24.

GibBs, H. C., AND R. P. Herd. 1986. Nematodiasis in cattle: Importance, species involved, immunity, and resistance. In The veterinary clinics of North America. Parasites: Epidemiology and control. Vol. 2, No. 2. H. C. Gibbs, R. P. Herd, and K. D. Murrell (eds.). W. B. Saunders, Philadelphia, Pennsylvania, p. 211-224.

JACQuiEt, P., J. CABARET, D. CheikH, AND E. Thiam. 1997. Identification of Haemonchus species in domestic ruminants based on morphometrics of spicules. Parasitology Research 83: 82-86.

KreceK, R. C., J. Boomker, B. L. Penzhorn, And L. Scheepers. 1990. Internal parasites of giraffes (Giraffa camelopardalis angolensis) from Etosha National Park, Namibia. Journal of Wildlife Diseases 26: 395-397.

LE JAMBRE, L. F. 1983. Pre-mating barriers to species hybridization in Haemonchus. International Journal for Parasitology 13: 365-370.

Lichtenfels, J. R., AND P. A. Pilitt. 2000. Synlophe patterns of the Haemonchinae of ruminants (Nematoda: Trichostrongyloidea). Journal of Parasitology 86: 1093-1098.

, L. M. Gibbons, And J. D. F. Boomker. 2001. Haemonchus horaki n. sp. (Nematoda: Trichostrongyloidea) from the grey rhebuck Pelea capreolis in South Africa. Journal of Parasitology 87: 1095-1103.

$\longrightarrow$, AND E. P. HoBERG. 1994. New morphological characters for identifying individual specimens of Haemonchus spp. (Nematoda: Trichostrongyloidea) and a key to species in ruminants of North America. Journal of Parasitology 80: 107-119.

- - AND L. F. LE JAMBRE. 1986. Cuticular ridge patterns of Haemonchus contortus and Haemonchus placei (Nematoda: Trichostrongyloidea). Proceedings of the Helminthological Society of Washington 53: 94-101. 
, AND — 1988. Spicule lengths of the ruminant stomach nematodes Haemonchus contortus, Haemonchus placei, and their hybrids. Proceedings of the Helminthological Society of Washington 55: 97-100.

, AND W. P. WERGin. 1994. Sublateral hypodermal cords in Haemonchus (Nematoda: Trichostrongyloidea): Description and potential as a systematic character. Journal of Parasitology 80: 620-624.

ORTLEPP, R. J. 1961. 'N oorsig van Suid-Afrikaanse helminte veral met verwysing na die wat in ons wildherkouers voorkom. Tydskrif vir Natuurwetenshappe, Pretoria I: 203-212.

Sachs, R., L. M. Gibbons, And M. F. Lweno. 1973. Species of Haemonchus from domestic and wild ruminants in Tanzania, East Africa, including a description of $H$. dinniki n. sp. Zeitschrift fur Tropenmedizin und Parasitologie 24: 467-475.

VAN DEN BERghe, L. 1937. Contribution a l'etude des parasites de l'Okapi (troisieme partie). Revue de Zoologie et de Botanique Africaines XXX, Fasc. 1: 117-139. 